Fecha de recepción: julio 2014

Fecha de aceptación: marzo 2015

Versión final: julio 2015

\section{The Transgressive Early Adopter: Being a Google Glass Explorer}

David R. Carroll *

Summary: With the advent of commercially available wearable computing devices, our technologically driven marketplaces accelerate an increasingly designed, mediated, and networked lifestyle where connected sensors, cameras, and display screens embed themselves onto our bodies rather than merely resting in our pockets and palms. This first phase of wearable computers includes bracelets containing sensors and wireless radios to track motion and activity toward a "quantified self" through data and personal context, mostly towards fitness and health objectives. Far less discreetly, Google Glass, the eyewear device with an integrated camera and a prism display positioned above the line of sight is perhaps the most startling and controversial new product that tests the boundaries of wearable utility and social acceptability. At the time of this writing, only hand-selected "Glass Explorers" are able to purchase the device as Google market-tests the product with "influencers" and early adopters. The author was accepted as an evaluation user of Glass and offers a personal and critical analysis of the experience here as a way of pointing towards a near future of increasingly wearable computing that infiltrates the body and its relationship to our social and spatial contexts.

Keywords: wearable computing - privacy - policy - Marketing - early adopters - contextual computing - Google - augmented reality - technology Etiquette - networked identity mobile computing - corporate gaze - fashionable technology - Silicon Valley - Advertising - dataveillance - surveillance - sousveillance - McVeillance - voice control - gesture control - bone conduction - transgressive technology - digital prosthesis - Steve Mann - glassholes - Molly Crabapple - Ernst Mach - Vannevar Bush - Caroline A. Jones.

[Summaries in spanish and portuguese at pages 166-167]

${ }^{*}$ Associate Professor of Media Design School of Art, Media, and Technology (Parsons The New School for Design).

\title{
Introduction
}

Google Glass is a truly novel product, not yet widely available to the market at the time of this writing, marketed with an unprecedented early adopter program. Only carefully "curated" purchasers are experiencing the abilities and liabilities of owning Glass right now. As a 
consequence, only audacious and well-funded scholars like myself have availed themselves of the opportunity to evaluate this transgressive design product, the wearable, networked, voice-activated, gesture controlled, head-mounted, bone-conducting, "corporate gaze" machine. We will need plenty of pending and future scholarship to more rigorously examine the impact of this vision of ubiquitous computing when it inevitably becomes more widely available to consumers, perhaps shortly after the publishing of this article. This transgressive technology deliberately aims to embed itself into everyday life, marketed as a means to make our computing devices more invisible and less intrusive.

However, Google Glass is neither subtle nor invisible. On the contrary, it is an overt display of corporate dataveillance. It attempts to persistently augment our point of view, skull mounted, physiological, and metaphysical. To others, it exclaims our personal endorsement of a hyper-networked persona presented as a corporate visage. Glass is a peculiar object of design in that it attempts to frame our field of vision with a layer of information space while it simultaneously advertises our complicity in our own expropriation. It's made by a company seeking to monetize the interests of advertisers and the market forces driven by unmet desires. Nothing brings them closer to this than the individualized perspective of my corporate gaze.

\section{Induction}

On February 22, 2013, I published a tweet with the hashtag "\#ifihadglass" in order to apply to the just announced Glass Explorers program (See Figure 1 at page 155) (Carroll, 2013). If selected by Google, based on my tweeted application, I would be entitled to purchase an early version of their wearable computer for US\$1500, provided I met the eligibility requirements and could accept delivery of the product in person in either San Francisco or New York City. On March 27, 2013, I was notified on Twitter that I had been selected to participate as an Explorer, and promptly used my academic research funds to place an order for the device and booked my appointment at the Google offices in Chelsea, Manhattan for July 18, 2013.

The employees selecting Glass Explorers must have considered a range of factors for the participants, especially the candidate's potential to function as an early adopter and help normalize the notion of wearing a camera, voice-controlled computer, and prism display above the right eye in public. My Twitter biography indicated my academic appointment at Parsons The New School for Design and likely credentialed me as a potentially valuable influencer for Google. In this sense, one could argue that I was paying for the privilege of marketing a controversial product, using the reputation of my academic institution to advance the "googlization of everything" (Vaidhyanathan, 2011) all in the name of research. This essay reflects upon being a transgressive early-adopter as a means to explore the implications of a near-future when these types of wearable technology transform social norms as fashionable computing devices that accelerate an increasingly designed, mediated, and networked lifestyle where connected sensors, cameras, and display screens begin to embed themselves onto our bodies rather than merely resting in our wrists, pockets, and palms. 
As my appointment approached to pick up Glass, I received several emails with exuberant language priming me for the special treatment I was about to experience. Indeed, Google had established a large salon in its Chelsea, Manhattan office complex dedicated to delivering the product to newly inducted Explorers. The workers all wore the headsets themselves, including the receptionist who signed me in upon arrival. Even if these devices did not serve any specific functions in the delivery process, it was a clear attempt to start normalizing the idea of wearing a computer on your face. I was greeted by a Glass-wearing concierge who would privately deliver the product, and give me an individualized fitting at a booth equipped with a mirror, snacks, and alcoholic drinks, perhaps to deliberately weaken my inhibition in the name of hospitality.
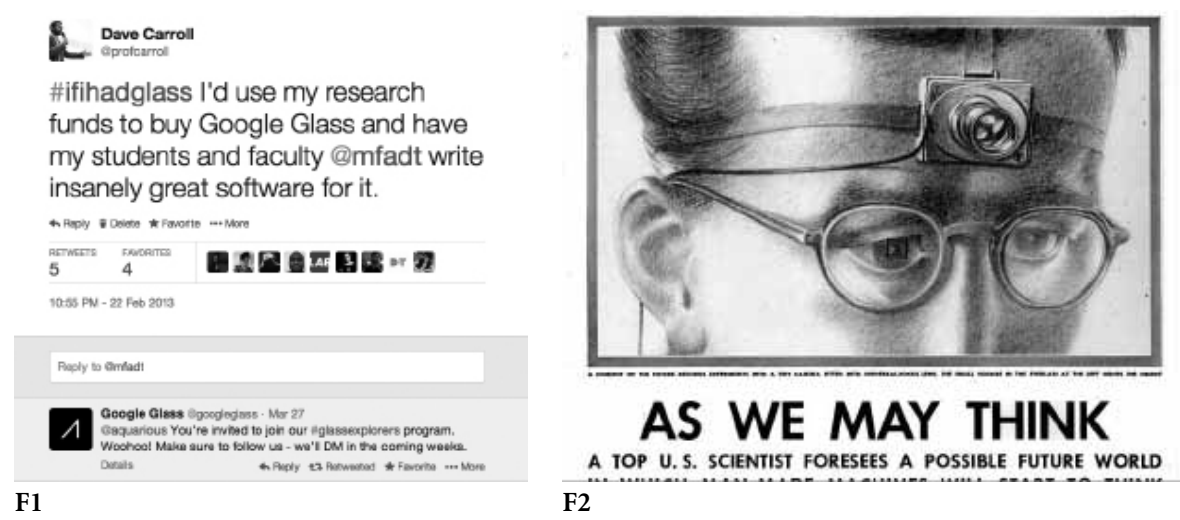

Figure 1. The Tweet that earned author the credential of Glass Explorer (Twitter, 2013). Figure 2. Illustration from LIFE Magazine September 1945 as referenced on WIRED (Sterling, 2011).

After getting equipped and oriented, I probed my concierge's general knowledge of computing history and the luminaries who had made a product like Glass possible. I called up Vannevar Bush's 1945 essay “As We May Think" first published in The Atlantic on the Google Chromebook laptop at our booth. This seminal essay describes a theoretical predigital, microfilm-based knowledge library appliance called the Memex that foreshadowed the Web and many aspects of Google's product line (Bush, 1945). I quickly found on Google Images Bush's illustration of a forehead mounted camera which might serve as an accessory to the Memex, recording a researcher's journey in a point-of-view through publications, as originally re-published in the September 10, 1945 issue of LIFE Magazine with illustrations (See Figure 2 at page 155). This seemed to surprise my Glass concierge that the notion of wearing a camera on one's head was not as novel and innovative as the popular perception. I delved further into his background knowledge, easily discovering that he had no prior encounter with Steve Mann and Thad Starner, two well-known engineering researchers who have been pioneering the field of wearable computing for decades. Thad Starner, a professor at Georgia Tech, is also an employee of Google and was 
a key contributor to the Google X skunkworks team that developed Glass. It seems the training program at Google did not include a lesson on the history of wearable computing or the company's role in enabling established researchers to bring fringe ideas to market.

\section{Privacy}

During the first weeks of wearing Glass, I experienced the amusing novelty value of being noticed on the streets and in the subway of New York City. Often other bystanders are heard whispering to each other, pointing, and taking photographs of me with their smartphones. In these moments, the public participates in a kind of sousveillance, capturing me wearing the device, perhaps assuming I am discreetly photographing them, conducting surveillance with my point-of-view perspective. Occasionally someone would approach me with questions, a cue to serve my role as the evangelist Explorer. Explain how they work, what it can do, but more importantly, what it can't do. People ask whether it employs facial recognition to instantly identify people by matching their images to online records. A startup released a Glassware application called Refresh that compiles virtual dossiers on the contacts in your various address books connected to your social media accounts cross-referencing to your Google Calendar appointments to predictively display this personal information based on your immediate context. It uses the analysis of your contacts and calendars to display the relevant profiles of people potentially in your field of view, achieving the same alarming effect without the use of computer vision techniques. (Grant, 2014)

Google, as a policy, forbids the use of the computer vision for the purposes of facial recognition by refusing to distribute applications that employ this functionality on their official Glassware app store. However, developers can supply unofficial applications to Explorers to be "sideloaded" onto their devices using the supplied USB cable and developer tools. A beta version of this type of product, NameTag, uses facial recognition techniques to identify people in the field of view of the Glass wearer. Senator Al Franken (D-MN), Chairman of the Senate Judiciary Committee on Privacy, Technology, and Law immediately issued an open letter to the founder of the NameTag product, Kevin Tussy, expressing his serious concerns about privacy on behalf of a federal legislative body that may soon undertake the task of regulating privacy issues related to wearable technology like Glass. (Franken, 2014)

I've also seen the faces of disapproval from those around me, visible discomfort with the characteristic lensless frame encircling my head, the prism hovering above my eye, my pupils occasionally wandering up to meet the translucence with a glowing aura. Wearing Glass on the New York City subway I mostly wondered if I was even noticed at all. Most of the passengers were always staring down at the devices in their palms. They did not even notice the smartphone on my face.

Shortly after receiving my XE headset from Google, the novelist Gary Shteyngart offered his experience in The New Yorker on August 5, 2013. I identified strongly with his firsthand experience but could never approach his skill at depicting it narratively with such a wry sense of humor. The highlight of his article is the description of using the Hangout 
video-chat feature of Glass with his friend, also wearing the device, using a feature meant for remote telepresence and the unintended metaphysical effect when they collide as bodies in real-life.

Before I leave, Aray and I have a Google "hangout". We essentially swap identities. I see what she sees through her Glass, which is me. She sees what I see through my Glass, which is her. We bring our faces closer, as if approaching a mirror, but the feeling is more akin to being trapped in an early Spike Jonze movie or thrust into an unholy Vulcan mind meld.

For the first time, Aray is not seamlessly woven into her technology. "I'm not going to lie", she says. "It's a little freaky". We give each other a hug as we part. (Shteyngart, 2013)

Shteyngart was prescient (or perhaps well-informed) referring to Spike Jonze, as his latest film, "Her (2014)" depicts the intimacy of the protagonist, played by Joaquin Phoenix, and his loving relationship with his near-future operating system that is entirely controlled and interfaced through artificial intelligence, voice synthesis, and speech recognition, as voiced by Scarlett Johanssen. Lacking a keyboard, Glass relies exclusively on the wearer's voice to input free-form text, replying on gesture controls on the temple only to browse and select through content on the prism display.

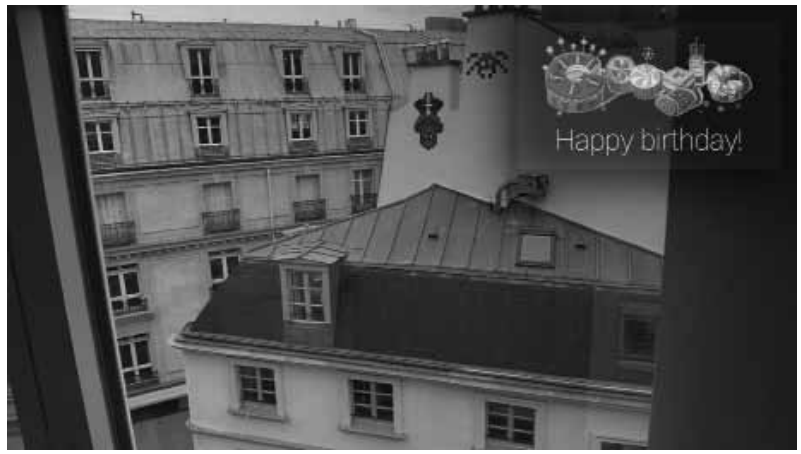

Figure 3. Glass wishing the author a Happy Birthday. (Carroll, 2014)

This compulsory act to speak to the device helps normalize the notion of speaking to a machine, not necessarily directly into a handheld device, as one interacts with Siri on an Apple iPhone. The character, Theodore, played by Phoenix, holds a smartphone-like device with an integrated camera in Her but wears a wireless earpiece in public. Otherwise, her voice is seamlessly piped in through speakers in his apartment. These fictional interactions of the omnipresent listener may refer to the future computers that we don't have to hold, but rather hold us, as "she" rests upon our body, always at the ready, with the flick of the 
neck, and a standard prompt, "ok glass" while exhibiting a propensity to read your email to remind you of your upcoming flights or even your birthday and disarm you with this personal intrusion with convincingly casual affectations (See Figure 3 at page 157). "Good morning, Theodore. You have a meeting in five minutes. You wanna try getting out of bed?" (Jonez, 2013)

\section{Fashion}

Wearing this product makes me feel audaciously futuristic but certainly not fashionable, more Segway than Savile Row. The September 2013 issue of Vogue featured the first instance of Glass presented in the fashion media as a design and style object (See the References for links to the images available on the Vogue website). The spread was shot by Steven Klein and fashion directed by Tonne Goodman at the Robert Bruno house (1974-2008). This rusted steel structure sited at the edge of Ransom Canyon, Texas was built by the architect himself and evokes an ancient futurism "like a lost spaceship - a fittingly modernist setting to display the shoot's most forward-looking accessory, Google Glass" ("Behind the pictures", 2013). The models wear "monochrome coats and suits" from contemporary but relatively mass-market designers including Oscar de la Renta, Gucci, Michael Kors, Bottega Veneta, Dior, Stella McCartney, and Calvin Klein while the "trio wanders through Ransom Canyon like future humans returned to an abandoned earth" as described in the caption accompanying the image titled "Forbidding Planet". The text for the spread delicately signals Google's imperial corporate hegemony for the photo titled "Command and Control" describing how the garments "purified lines and simplified structures are a perfect fashion strategy for taking over the office (or taking over the planet)". The image depicts the model sitting at a glass desk in front of a computer screen, her Google Glass prism display is sparkling with activity, her hand is posed as if she is holding a phantom mouse for the computer that is gradually vanishing. We aren't sure if she is looking at the images in her Glass, the computer monitor on the desk, or the couple standing outside the window. Perhaps she sees all three at once. (Klein, 2013b)

The most comical image in the series titled "Bang! Pow!" features two models posed as if caught in an altercation, wearing Glass with the sunglass lens attachments and orange and navy jersey dresses from Tom Ford. Their dresses offer the only decorative motifs on the otherwise monochromatic suits shown in this peculiar Vogue spread. An observing Glass wearer watches the fight from the left foreground of the image, as if the burst patterns on the dresses are imagined as a visual element superimposed by Glassware to mark the social transgressions of the combatants in the field of view. Of all the images in the series, this one most overtly expresses the anxiety of bystanders under peer surveillance through its implied narrative. (Klein, 2013c) 


\section{McVeillance}

Steve Mann, an early pioneer in the field of wearable computing, even dubbed by some as the "father of wearable computing," has been wearing a custom computer vision system for at least 34 years. Recently, he has been using a device called EyeTap, which is a sophisticated augmented reality system, that covers his right eye and uses laser sighting that enables the mechanical digital eye to emulate natural eye movements and image processing. Mann's research is focused on vision augmentation research for the blind and visually impaired. His accomplishments in the field are well-recognized.

During the summer of 2013, he took a vacation with his family to Paris, France, visiting numerous tourist destinations including museums with strict photography restrictions. He carries a physician's letter and official documentation that he normally presents to gain access to facilities with his experimental wearable computing equipment that is not removable from his skull without special tools. On July 1, he brought his family to the McDonald's at 140, Avenue Champs Elysees and was allegedly assaulted by purported employees who reviewed and destroyed his documentation and attempted to forcibly remove the EyeTap device from his face. His equipment automatically recorded the incident and he published these details on his Website (Mann, 2013). Ray Kurzweil, the noted futurist, proclaimed the incident as "the first attack on a cyborg" and indicated the potential for these incidents to be classified as hate crimes (Kurzweil, 2013). The corporate policy of McDonald's is to strictly forbid photography in its restaurants, presumably to protect trade secrets of its merchandising and the employees who confronted Mann did so for enforcement. Mann subsequently classified a distinct form of surveillance conditions as "McVeillance" whereby an entity conducts camera based monitoring on its clients but vigorously prohibits any reciprocal image capture. (“Steve Mann”, 2013)

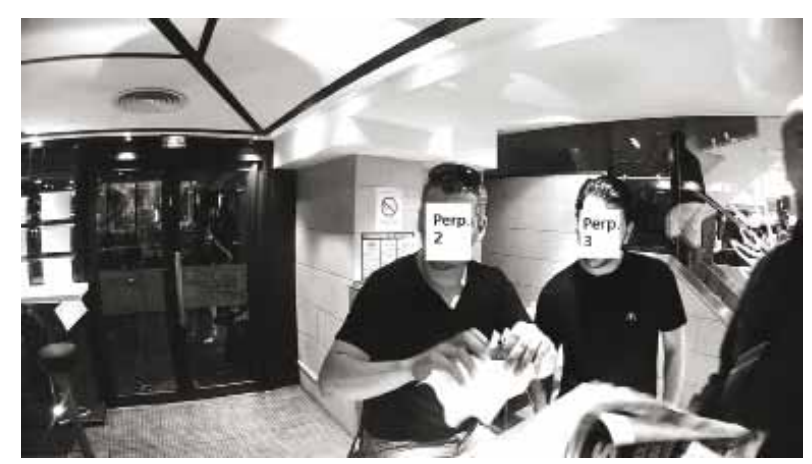

Figure 4. Perpetrator 2 tearing up my doctor's letter, while Perpetrator 3 watches. (Mann, 2013)

In response to this incident, the IEEE, ACLU, and Pete Wassel, CEO of Augmente Corporation, collaborated with Mann and presented a draft of new legislation on 
November 20, 2013 to the New York State Senate and Assembly titled the Mann-Wassel Law that would protect the rights of individuals to conduct sousveillance (or reverse surveillance) with the use of wearable computing devices, such as Mann's EyeTap and Google Glass. (Wassel, 2013) At the time of this writing, a legislator from New York State has not sponsored the proposal for consideration as a bill.

Wearable device assault incidents tend to be recorded in point-of-view video, offering a strange new kind of evidence potentially admissible for criminal investigations. While I wrote this paper, reflecting upon Steve Mann's incident in Paris, a "social media consultant" named Sarah Slocum was allegedly assaulted at Molotov Bar in San Francisco on February 22, 2014 by patrons who believed she was recording them without permission. The incident has been described in the press as a particular rejection of invasive wearable technology and a failure of an Explorer to observe socially acceptable etiquette. More broadly though, this event symbolizes the backlash against "tech companies like Google, Twitter and others" that Slocum's attackers claimed to be "destroying" the city with their unique brands of corporate imperialism (Tsukayama, 2014). Even in the technologycentric city of San Francisco, Glass Explorers risk physical assault and personal danger if they decide to disregard the newly emerging social etiquette of wearable technology.

\section{Reaction}

Google is keenly aware of the slang term "glasshole" that immediately emerged in the popular technology discourse to describe the creepy and rude behavior of a typical wearer, most often a white male. An anonymous Tumblr site compiles evidence to support this stereotype (Anonymous, 2014). The company offers an etiquette guide to Explorers with a list of basic DOs (e.g., Ask for permission) and DON'Ts (e.g., Wear it and expect to be ignored) (Google). These guidelines are derived from the active Explorer community who post to the provided message forums as a means to relate their experiences with fellow early-adopters. Here, they have offered common sense suggestions for contending with curious members of the public as well as people and institutions, who consider the device intrusive and an instrument of contested space. The company knows it needs more than its Explorer evangelists to condition the public to the device and announced upcoming "road shows" in select cities to set up pop-up salons where the curious can try out the product, with an emphasis on local politicians and other potential influencers. (Lardinois, 2014)

In stark contrast to the typical white male Silicon Valley "glasshole" archetype cataloged in the referenced Tumblr site, the artist Molly Crabapple published an entry on Rhizome describing her admittedly pop-feminist understanding of how Glass could be employed to subvert the male, corporate gaze. She livestreamed the process of sketching her friend, Stoya, the "porn star and aerialist" in Glass-enabled POV (Crabapple, 2014). Perhaps not a high point of feminist art, and Crabapple admits her limitations here, the understanding of her role as an Explorer pertains to the question of being a transgressive early adopter for Google, an actor who is "not neutral" because we the "shock troops of empire". She extends her artistic impetus to a critical impression of the French Impressionist painter, 
Edgar Degas as the "classic creepster, a client of sex workers" with a "fetish for workingclass women" known for "supplementing their income with sex work" while "Degas just watched". Crabapple redirects this exploitation of objectified women toward a critique of a gender-neutral expropriation of our collective identities by Silicon Valley dataveillance firms, that somehow the presence of a wearable appliance on our faces makes blatantly obvious, where it is usually far more invisible, subtle, and subversive when we merely use a laptop, tablet, or smartphone.

In the networked world, we are all sharecroppers for Google. We take our deepest selves and turn them into light on glass cables, to be sold as marketing data or sandwiched between ads. Google Glass takes this further. With it, the act of looking can be separated from the looker. Eye speed can be tracked. Gaze can be owned. The consumer becomes the consumed. (Crabapple, 2014)

To Crabapple, wearing Glass enables the imperial motives of Google to conquer all aspects of our daily lives, and serves as an opportunity to make more visible their quest to monetize our every gesture towards targeted marketing and hyper-personalization. Trying to be critical about technology with technology is a contradiction. While hoping not to be derided as a creepy "glasshole," an Explorer can literally glimpse into a future of pervasive networked electronics. It allows us to contemplate how this might be empowering or enslaving. Opt-out and you cannot feel the sensation to offer an informed critique. Optin and you're a complicit shock trooper.

\section{Iteration}

Despite the lack of civil protections to use wearable photography equipment in public and private establishments, Google remains undeterred in its marketing effort to condition its product towards acceptability. The first edition of Glass XE (Explorer Edition) contained a special Demo Mode, which temporarily disabled the personal accounts of the device owner, replacing the personalized content with off-the-shelf generic samples. This allowed an Explorer to activate the demonstration mode and confidently hand the device to someone else to try on. They experience it without the risk of posting images to the owner's social networks, a task that is exceptionally easy to trigger with voice and finger gestures on the temple touch pad. Clearly, Google designed the product as to enable the early-adopters to serve as product representatives, equipped with tools to respond to the curiosity of friends and strangers alike and gain confidence in sharing a very private set of functionalities.

On December 16, 2013, I received notice to send back my Glass for the second edition, no charge. A pre-paid shipping box was on its way and an updated model would arrive shortly after with an ear-piece accessory. Explorers consistently provided feedback that the bone-conduction system of transmitting audio through skull vibrations was insufficient in many environments. The Demo Mode feature was removed in the new model, replaced 
with new experimental features such as one that allows the wearer to simply wink to take a photograph. The second edition also included support for two new features to improve an Explorer's ability to share the wearing experience with others. This includes a Make Vignette command to take screenshots and a screencasting capability to show the contents of the prism display on a paired smartphone display. Make Vignette allows the wearer to superimpose a screenshot of the prism display's contents onto the POV image to simulate how Glass augments the field of view in a specific moment (See Figure 2 at page 155). Both of these features are expressly implemented to enhance the role of the Explorer as an evangelist and explainer to the uninitiated and share what it looks like with others. Here we see how Google has been responding to early-adopter feedback and exploiting the opportunity to test the boundaries of acceptable features with more audacious interactions like wink-to-capture while improving practical matters like audio reproduction.

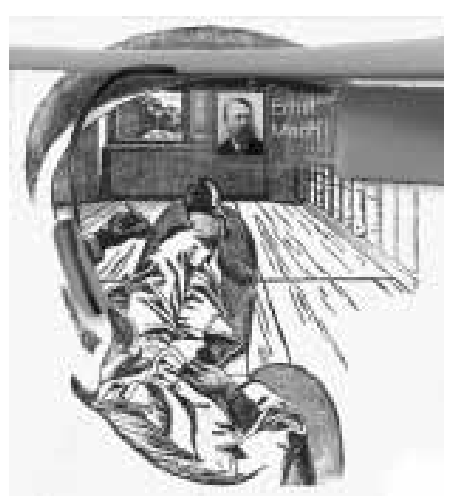

F5

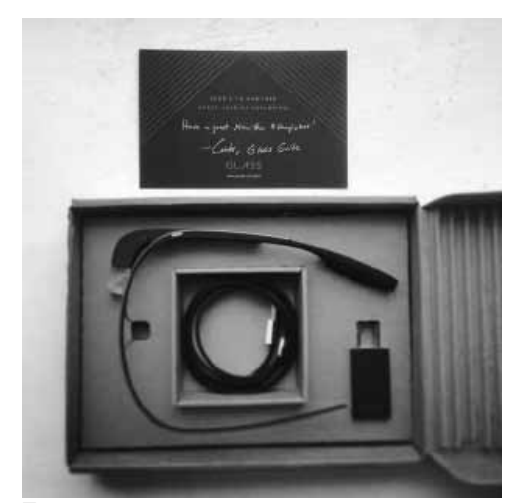

F6

Figure 5. Return box for XE first edition model. Happy New Year card from my fitting concierge. (Carroll, 2014). Figure 6. Photo-illustration by author of Ernst Mach wearing Google Glass adapted from his Figure 1 in Beiträge zur Analyse der Empfindungen (1886; translated as Contribution to the Analysis of Sensations, Chicago 1897).

\section{Physiology}

Wearing technology on our heads is a normative public behavior with bulky DJ-style headphones serving as a common trendy fashion statement. Ever since the Sony Walkman in the 1980s and the Apple iPod in the 2000s, the technological apparatus of portable listening has been made ordinary by the marketplace. As the quantified-self movement cultivates a market for health and fitness enthusiasts to track their activity through accelerometer sensors embedded in networked bracelets, we observe an acceptance of useful dataveillance. However, the data bracelet is more discreet than the bulky headphones and characteristic white earbuds. Will the market succeed at selling and mainstreaming 
networked electronic equipment to augment our vision in the same manner? Is it inevitable, even predestined?

On the occasion of the Synthetic Times exhibition of 2008 at the National Art Museum of China, Beijing, the largest assembly of international new media art to date, Caroline A. Jones framed the section of works contending with the human body and our dependency on media in her catalog essay "Going Beyond the Body" which opened by examining a fascinating drawing by the Austrian physicist and philosopher, Ernst Mach (1838-1913). Rendered from the perspective of seeing out of one eye, his illustration encapsulates the physiological condition of our human anatomy, that we see our appendages sticking out from our body, but we cannot understand the wholeness of our body without the assistance of a mirror, a camera, or more broadly, the media, an image of ourselves rendered whole. As Mach observed, "My body differs from other human bodies, by the circumstances that it is only seen piecemeal, and especially, is seen without a head". (Mach, 1897)

Jones extends this paradox as a basic pursuit of media culture because the mysteries of our body's "sensations firing in patterns that so far have been far more accurately interpreted by culture than by science". She goes as far as situating the essential purpose of art and representations as our penchant for "compulsively figuring animals, people, and gods in search of confirmation that we are whole, intact, and belong to something larger than ourselves". Indeed, since we are stuck in our skulls, peering out of an anatomical Plato's cave, in a quest for our integrity, we "must seek it elsewhere: in the face of the other, in representations, in simulacra. The seductions of media begin here". (Jones, 2008)

\section{Conclusion}

There's no doubt I am a conflicted Explorer, sometimes feeling as if I'm transgressing against social, academic, and ethical norms. As a special customer of a massive company whose stated mission is "to organize the world's information and make it universally accessible and useful" I estimate how it may exploit my professional reputation for its own marketing purposes. Far beyond this soft transaction, by wearing Glass, I endorse the branding of my face, my most unique form of interpersonal identification. My most intimate and personal gesture, my gaze, I allow to be commercialized so that our profound experience of being human, literally our world-view, might be somehow optimized, enhanced, and organized for the advancement of the species. The total cost of owning Glass is tremendous, well beyond the steep price of the equipment itself, as my corporate gaze advantages a dataveillance incumbent to further monetize not only my expressions, thoughts and presentation of a virtual identity, but most invasively it conscripts me to volunteer as a promoter of the acceptability of their product line while devising a way to see the world the way I see it. Who is exploring whom?

The vectors of technology, design, and humanity have accelerated us towards wearable computing for centuries. Mach in the 19th century could not have predicted the availability of a product precisely like Glass but he helped us see how we see, how we might be physiologically conditioned to seek a prosthesis. Bush envisioned a wearable head-mounted product in 1945 before the advent of digital computing at the end of the 
20th century because he saw the need for a massive reorganization of knowledge through a new media. It would offer accessibility and optimization through new technology interfaces. Researchers like Mann and Starner would soon help commercialize the prosthetic computation devices of the 21 st century while leaving the problem of social normalization to marketing professionals. Critics and historians like Crabapple and Jones illuminate our intrinsic anxieties originating from this propensity to be seduced by media, a technology that enables the gaze.

To commemorate Mach in the age of Google, I offer my own absurd photo-illustration of Ernst Mach's original illustration (See Figure 6 in page 162), himself seeing himself out of his skull, but now anachronistically wearing Glass, finding his own image after a voice command, and virtually completing his self-image, overcoming the metaphysical obstruction of his anatomy with a digital prosthesis. In our contemporary hyperconnected world, as our identity is further fragmented, contested, and commercialized, we may wear a pervasive display that not only assures us of our escape from the black box of our physiology but also delivers us a constant assurance that our networked persona is nurtured, omnipresent, and sustained in its dispersal within the Cloud. I'm whole, intact and people "like" me.

\section{Acknowledgements}

Special thanks to Ambreen Hussain for insightful and meticulous draft comments, Cynthia Lawson for helping me hone my argument, Jasonpaul McCarthy for valuable input on the fashion spread analysis, and to Steven Faerm for the encouragement to pursue this topic.

\section{References}

Anonymous. (2013, December 12). White men wearing Google Glass. Retrieved from http:// whitemenwearinggoogleglass.tumblr.com/

Behind the pictures: Tonne Goodman. Vogue. (2013, August 21). Retrieved from http://www. vogue.com/vogue-daily/article/behind-the-pictures-tonne-goodmans-the-final-frontier/ Bush, V. (1945, July 1). As we may think. The Atlantic. Reprint retrieved from http://www. ps.uni-saarland.de/ duchier/pub/vbush/vbush-all.shtml

Carroll, D. (profcarroll). “\#ifihadglass I'd use my research funds to buy Google Glass and have my students and faculty@mfadt write insanely great software for it”. 22 February 2011, 10:55 p.m. Tweet. Retrieved from https://twitter.com/profcarroll/status/305163836074389504

Carroll, D. (2014, February 11). Birthday 'make vignette' command generated POV image. [Google Glass image JPG file]. Retrieved from http://pic.twitter.com/4qBx3lTB7L

Carroll, D. (2014, January 1). Instagram. Retrieved from http://instagram.com/p/irCBUG ItbD/

Crabapple, M. (2014, January 7). Google Glass, the corporate gaze and mine. Rhizome. Retrieved from http://rhizome.org/editorial/2014/jan/7/google-glass-male-gaze-andmine/ 
Franken, A. (2014, February 4). NameTag letter, United States Senate, Committee on the Judiciary. Retrieved from http://www.franken.senate.gov/files/letter/140205NameTagLetter. pdf

Grant, R. (2014, February 6). Refresh unveils Google Glass app that presents 'instant dossiers' on people you meet. VentureBeat. Retrieved from http://venturebeat.com/2014/02/06/ refresh-unveils-google-glass-app-that-presents-instant-dossiers-on-people-you-meet/

Google. (n.d.). Google Glass Explorers. Retrieved from https://sites.google.com/site/ glasscomms/glass-explorers

Jones, C. A. (2008). Going beyond the body. In Fan, D. \& Zhang, G. (Ed.), Synthetic Times. (1st ed., pp. 30-45) Cambridge, MA Beijing, China: MIT Press National Art Museum of China. Jonze, S. (Writer, Director, Producer) (2013). Her [Motion Picture]. United States: Warner Bros. Pictures.

Klein. S. (2013, August 21). Google Glass and a Futurist Vision of Fashion. Vogue. Retrieved from http://www.vogue.com/magazine/article/the-final-frontier-google-glass-andfuturistic-fashion/

Klein, S. (2013, August 21). Command and Control. Vogue. [photo, JPG file]. Retrieved from http://www.vogue.com/magazine/article/the-final-frontier-google-glass-and-futuristicfashion/\#/magazine-gallery/the-final-frontier/5

Klein, S. (2013, August 21). Bang! Pow!. Vogue. [photo, JPG file]. Retrieved from http://www. vogue.com/magazine/article/the-final-frontier-google-glass-and-futuristic-fashion/\#/ magazine-gallery/the-final-frontier/6

Kurzweil, R. (2013, July 17). First attack on a cyborg. Retrieved on 2014 February 24 from http://www.kurzweilai.net/first-attack-on-a-cyborg

Lardinois, F. (2014, February 9). Google Hopes its Roadshows Will Help Normalize Glass. TechCrunch. Retrieved from http://techcrunch.com/2014/02/09/google-hopes-itsroadshows-will-help-normalize-glass/

Mach, E. (1897). Contribution to the Analysis of Sensations [italicized as is]. (Dover, 1959 ed., p. Section 9). Chicago: The Open Court Publishing Company.

Mann, S. Left-to-right: Perpetrator 2 tearing up my doctor's letter, while Perpetrator 3 watches. Steve Mann's Blog. Retrieved from http://eyetap.blogspot.fr/2012/07/physicalassault-by-mcdonalds-for.html

Mann, S. (2013, July 17). Physical assault by McDonald's for wearing Digital Eye Glass. Retrieved from http://eyetap.blogspot.com/2012/07/physical-assault-by-mcdonalds-for.html

Shteyngart, G. (2013, August 5). O.K., Glass: Confessions of a Google Glass Explorer. The New Yorker. Retrieved from http://www.newyorker.com/reporting/2013/08/05/130805fa fact_shteyngart?currentPage $=$ all

Seymour, S. (2008). Fashionable Technology: The Intersection of Design, Fashion, Science, and Technology. New York, NY: Springer.

Sterling, B. (2011). Augmented Reality: Vannevar Bush Cyclops Camera. Wired. Retrieved from http://www.wired.com/beyond_the_beyond/2011/07/augmented-reality-vannevarbush-cyclops-camera/

Steve Mann. (n.d.) In Wikipedia. Retrieved 2014 February 24 from https://en.wikipedia. org/wiki/McVeillance\#McVeillance_and_the_Mann-Wassel_Law 
Tsukayama, H. (2014, February 26). Anti-Google Glass attack in San Francisco highlights tension over wearables. The Washington Post. Retrieved from http://www.washingtonpost. com/business/technology/anti-glass-attack-in-san-francisco-highlights-tensionoverwearables/2014/02/26/b3f21e44-9eeb-11e3-9ba6-800d1192d08b_story.html

Vidhyanathan, S. (2011). The Googlization of Everything: (And Why We Should Worry). Berkeley: University of California Press.

Wassel, P. (2013, November 20). Proposed law on sousveillance. Retrieved from http://www. webcitation.org/6DGWgAmau

Resumen: Con el advenimiento de los dispositivos informáticos portátiles disponibles en el mercado, nuestros mercados impulsados por la tecnología aceleran un estilo de vida cada vez más diseñado, mediatizado, y en red, donde los sensores conectados, cámaras y pantallas de visualización se incrustan en el cuerpo en lugar de simplemente descansar en nuestros bolsillos y en las palmas de nuestras manos. Esta primera fase de las computadoras portátiles incluye pulseras que contienen sensores y radios inalámbricas para rastrear el movimiento y la actividad hacia un "ser cuantificado" a través de los datos y el contexto personal, sobre todo hacia los objetivos de fitness y de salud. Mucho menos discretamente, Google Glass, el dispositivo de gafas con una cámara integrada y una pantalla prisma colocado por encima de la línea de visión es quizás el nuevo producto más sorprendente y polémico que pone a prueba los límites de la utilidad de vestir y aceptabilidad social. Al momento de escribir este artículo, sólo unos pocos selectos Glass Explorers, pueden hoy adquirir este dispositivo ya que Google está testeando el producto con "influenciadores" y "compradores pioneros". El autor fue aceptado como usuario para la evaluación de Google Glass y ofrece aquí un análisis y crítica personal de la experiencia como una manera de apuntar hacia un futuro cercano de una informática cada vez más portátil que se incorpora al cuerpo y su relación con los contextos sociales y espaciales.

Palabras clave: computación usable - privacidad - política - Marketing - compradores pioneros - computación contextual - Google - realidad aumentada - tecnología Etiquette - identidad en red - computación móvil - enfoque corporativo - moda tecnológica - Silicon Valley - Publicidad - vigilancia de datos - vigilancia sub-supervisión - McVeillance - control de voz - control de gestos - conducción ósea - tecnología transgresora - prótesis digital - Steve Mann - hoyos de vidrio - Molly Crabapple - Ernst Mach - Vannevar Bush - Caroline A. Jones.

Resumo: Com o advento dos dispositivos informáticos portáteis disponíveis no mercado, nossos mercados impulsionados pela tecnologia aceleram um estilo de vida cada vez mais desenhado, mediatizado e em rede, onde os sensores conectados, câmaras e telas de visualização se incrustam no corpo em lugar de simplesmente descansar nossos bolsos e nas palmas das nossas mãos. Esta primeira fase dos computadores portáteis inclui pulseiras que contêm sensores e rádios sem fio para localizar o movimento e a atividade até um "ser quantificado" através dos dados e o contexto pessoal, sobretudo até os objetivos de fitness 
e de saúde. Muito menos discretamente, Google Glass, o dispositivo de óculos com uma câmara integrada e uma tela prisma colocada por cima da linha de visão é talvez o novo produto mais surpreendente e polêmico que põe à prova os limites da utilidade de vestir e aceitabilidade social. Ao momento de escrever este artigo, só uns poucos seleitos "glass explorers" podem hoje adquirir este dispositivo já que Google está testando o produto como "influenciadores" e "compradores pioneiros". O autor foi aceitado como usuário para a avaliação de Google Glass e oferece aqui uma análise e crítica pessoal da experiência como uma maneira de apontar até um futuro próximo de uma informática cada vez mais portátil que se incorpora ao corpo e sua relação com os contextos sociais e espaciais.

Palavras chave: computação - usável - privacidade - política - marketing - compradores pioneiros - computação contextual - Google - realidade aumentada - tecnologia - Etiquette - identidade em rede - computação móvel - enfoque corporativo - moda tecnológica Silicon Valley - publicidade - vigilância de dados - vigilância sub-supervisão - McVeillance - controle de voz - controle de gestos - condução óssea - tecnologia transgressora - prótese digital - Steve Mann - buracos de vidro - Molly Crabapple - Ernst Mach - Vannevar Bush - Caroline A. Jones. 